\title{
Hsa_circ_00069 I6 Knockdown Represses the Development of Hepatocellular Carcinoma via Modulating miR-599/SRSF2 Axis [Retraction]
}

\author{
Zhu Z, Shen S, Zhao S, Wang Z. Onco Targets Ther.
} 2020;13:11301-11313.

At the authors request, the Editor and Publisher of OncoTargets and Therapy wish to retract the published article. The authors informed the journal that the author, Sen Zhao, was added to the paper as an author without their knowledge or permission. In addition, the authors have also informed the journal that no ethical approval was given by the ethics committee of the First Affiliated Hospital of Henan University despite the article stating research approval had been provided. Given both issues breach our editorial policies the authors decided to retract the article.

Our decision-making was informed by our policy on publishing ethics and integrity and the COPE guidelines on retraction.

The retracted article will remain online to maintain the scholarly record, but it will be digitally watermarked on each page as "Retracted".

\section{Publish your work in this journal}

OncoTargets and Therapy is an international, peer-reviewed, open access journal focusing on the pathological basis of all cancers, potential targets for therapy and treatment protocols employed to improve the management of cancer patients. The journal also focuses on the impact of management programs and new therapeutic agents and protocols on patient perspectives such as quality of life, adherence and satisfaction. The manuscript management system is completely online and includes a very quick and fair peer-review system, which is all easy to use. Visit http://www.dovepress.com/ testimonials.php to read real quotes from published authors. 